\title{
OCCURRENCY OF MALASSEZIA PACHYDERMATIS AND OTHER INFECTIOUS AGENTS AS CAUSE OF EXTERNAL OTITIS IN DOGS FROM RIO GRANDE DO SUL STATE, BRAZIL (1996/1997)
}

\author{
Márcia de Oliveira Nobre ${ }^{1 *}$; Ângela Pötter de Castro ${ }^{2}$; Patrícia da Silva Nascente ${ }^{1}$; \\ Laerte Ferreiro ${ }^{2}$; Mario Carlos A. Meireles ${ }^{1}$
}

\begin{abstract}
${ }^{1}$ Faculdade de Veterinária, Departamento de Veterinária Preventiva, Universidade Federal de Pelotas, Pelotas, RS, Brasil. ${ }^{2}$ Faculdade de Veterinária, Setor de Micologia, Departamento de Patologia Clínica Veterinária, Universidade Federal do Rio Grande do Sul, Porto Alegre, RS, Brasil
\end{abstract}

Submitted: December 05, 2000; Returned to authors for corrections: February 08, 2001; Approved: September 03, 2001

\begin{abstract}
The purpose of this work was to evaluate the frequency of Malassezia pachydermatis infection and other infectious agents in dogs with external otitis and with healthy auditory tubes. Clinical manifestations of external otitis were evaluated. Samples from the auditory tube of 102 dogs with otitis and from 32 healthy dogs were submitted to direct microscopic examination and cultured in blood agar and Sabouraud dextrose agar with chloramphenicol and cycloheximide. Direct examination showed more than ten cells of $M$. pachydermatis in $52.0 \%$ of the samples from dogs with otitis, but in only $21.8 \%$ of the healthy auditory tube samples. $M$. pachydermatis was isolated in $37.5 \%$ of the samples from dogs with healthy auditory tube and $76.5 \%(\mathrm{p}<0.01)$ of the samples from dogs with otitis. There was an association between M. pachydermatis and Staphylococcus aureus ( $\mathrm{p}<0.01)$, but not with Pseudomonas aeruginosa ( $\mathrm{p}>0.05$ ). Infection by M. pachydermatis was prevalent in the following breeds: Cocker Spainel, German Shepherd and Brazilian Fila. No differences were found in frequency of the infection in relation to age, sex and ear anatomy of the dogs. Otomycosis were predominantly ceruminous and erythematous. M. pachydermatis was the most frequent agent in external otitis.
\end{abstract}

Key words: Malassezia pachydermatis, Staphylococcus aureus, otitis, dog

\section{INTRODUCTION}

The genus Malassezia belongs to the family Cryptococcaceae, order Cryptococcales class of Blastomycetes division Deuteromycotina (14). It is composed by yeasts with a thick cellular membrane, with multiple layers. The reproduction is asexual, with production of blastoconidia through a repetitive single polar process or budding, forming a round, ovoid or cylindrical cell when it separates from the mother cell. $M$. pachydermatis is the only species of the lipophilic-nondependent genus. Morphologically it comes as an isolated or a grouped cell, with oval format or with single polar budding of wide base, acquiring the format of a "bottle". Hypha and pseudohypha are usually absent $(2,12)$.
M. pachydermatis is a common component of the microbiota of the domestic carnivores skin. It is also isolated in external otitis and dermatitis. The cellular multiplication is facilitated when there is a change in the microenvironment, excessive production of earwax, $\mathrm{pH}$ alteration, after antibiotics therapy or in allergic cases (11).

The pathogenicity of $M$. pachydermatis was confirmed through experimental inoculation of dogs with healthy auditory tubes. They showed clinical signs 21 days after inoculation, histopathological lesions and presence of yeast. The control group was negative (19).

The aims of the present work were to study the occurrence of M. pachydermatis and other etiological agents in dogs with external otitis and their possible associations; and to characterize

\footnotetext{
* Corresponding author. Mailing address: Faculdade de Veterinária, Universidade Federal de Pelotas, Campus Universitário. 96010-000, Pelotas, RS, Brasil, E-mail: monobre@terra.com.br
} 
the otomycosis in relationship with breed predisposition, conformation of the auricular pavillion, sex, age, evolution, clinical signs and lesions.

\section{MATERIALS AND METHODS}

From May 1996 to April 1997, the presence of Malassezia sp was searched in the ear canal from dogs with external otitis and from healthy dogs. Dogs from several breeds and ages were examined (Table 1). A total of 134 samples was analyzed and divided in two groups. Group I was composed by 32 samples from dogs with healthy auditory tubes and group II by 102 samples from dogs with external otitis. The samples were collected from dogs that were taken to the Veterinary Hospital, Federal University of Pelotas (Brazil) and in private clinics of towns from the South and Midwest of Rio Grande do Sul state (Brazil).

In Group I, all dogs were previously evaluated by otoscopy and showed no clinical signs or otitis lesions: 12 samples came from pendular ears, eight from semi-pendular and 12 from erect ears. The samples belonged to the Group II were collected from 72 cases of external otitis with chronic evolution (more than one month), six from external otitis whit acute evolution (up to one month) and 24 without history: 67 sample belonged to dogs pendular ears, six from semi-pendular, 26 from erect ears and three with no information. In 93 cases the otitis was unilateral and in eight unilateral.

The samples were taken with the aid of a sterile swab, moistened in saline solution and rubbed in the anterior ear canal. The detection of $M$. pachydermatis in the ear discharge was performed by direct examination of the smear. Slides were stained with Gram or Loeffler for cytologic examination. According to the number of yeast cells per microscopic field it was applied the following score: - negative; + from one to five cells; ++ from six to ten cells and +++ more than ten cells.

The samples were cultivated in Sabouraud dextrose agar with chloramphenicol $(0.4 \mathrm{~g} / \mathrm{l})$ and cycloheximide $(0.5 \mathrm{~g} / \mathrm{l}) \mathrm{kept}$ at $37^{\circ} \mathrm{C}$ for up to ten days, and examined macroscopic and microscopic evaluation. For bacterial isolation all the samples were cultivated in agar with $8 \%$ of defibrinated sheep blood and incubated for up to 72 hours. Morphological and biochemical characterization were performed.

The results were analyzed by the Epi Info version 5.01b. Afterwards the variables were codified and crossed in two by two table, using the Qui-square and Fischer's tests.

\section{RESULTS AND DISCUSSION}

\section{Direct examination}

Twenty-five samples from the Group I (78.1\%) were negative for $M$. pachydermatis. One (3.1\%) had from one to five cells per field $(++)$ and six $(18.7 \%)$ had one to five cells $(+)$ (Table 2$)$.
Table 1. Distribution of dogs with healthy auditory tubes and external otitis regarding breed, age and sex in samples from Southern and Midwest regions of Rio Grande do Sul, Brazil (1996 - 1997).

\begin{tabular}{|c|c|c|c|c|c|c|c|c|c|}
\hline \multicolumn{10}{|c|}{ GROUP I } \\
\hline \multirow[t]{2}{*}{ BREEDS } & \multirow[t]{2}{*}{$\mathrm{n}$} & \multicolumn{4}{|c|}{ AGE (years) } & \multirow{2}{*}{\multicolumn{2}{|c|}{$\begin{array}{l}\geq 8 \\
\mathrm{n}^{\mathrm{o}}\end{array}$}} & \multicolumn{2}{|c|}{ SEX } \\
\hline & & $\begin{array}{l}\leq 1 \\
\mathrm{n}^{\mathbf{o}} \\
\end{array}$ & $\begin{array}{c}2-3 \\
\mathrm{n}^{\mathrm{o}}\end{array}$ & $\begin{array}{c}4-5 \\
n^{0} \\
\end{array}$ & $\begin{array}{c}6-7 \\
\mathrm{n}^{\mathrm{o}} \\
\end{array}$ & & & $\begin{array}{l}\mathrm{M} \\
\mathrm{n}^{\mathrm{o}}\end{array}$ & $\begin{array}{l}\mathrm{F} \\
\mathrm{n}^{\mathrm{o}} \\
\end{array}$ \\
\hline Cocker Spaniel & 2 & - & - & 2 & - & & - & 2 & - \\
\hline Collie & 2 & - & - & - & - & & 2 & 2 & - \\
\hline Danish & 3 & - & 3 & - & - & & - & 2 & 1 \\
\hline Brazilian Fila & 4 & 2 & 2 & - & - & & - & 2 & 2 \\
\hline Labrador & 2 & - & 2 & - & - & & - & 2 & - \\
\hline German Shepherd & 2 & - & - & - & 2 & & - & - & 2 \\
\hline Miniature Pinscher & 2 & - & - & - & - & & 2 & - & 2 \\
\hline Poodle & 5 & 2 & 3 & - & - & & - & 2 & 3 \\
\hline Schnauzer & 2 & 2 & - & - & - & & - & - & 2 \\
\hline Brazilian Terrier & 2 & - & - & - & 2 & & - & 2 & - \\
\hline WDB & 6 & - & - & 6 & - & & - & 2 & 4 \\
\hline Total & 32 & 6 & 10 & 8 & 4 & & 4 & 16 & 16 \\
\hline \multicolumn{10}{|c|}{ GROUP II } \\
\hline \multirow[t]{3}{*}{ BREEDS } & & $\mathrm{n}$ & \multicolumn{3}{|c|}{ AGE (years) } & & & \multicolumn{2}{|c|}{ SEX } \\
\hline & & $\leq 1$ & $2-3$ & $4-5$ & $6-7$ & $\geq 8$ & $\mathrm{NI}$ & M & $\mathrm{F}$ \\
\hline & & $\mathrm{n}^{\mathrm{o}}$ & $\mathrm{n}$ & $\mathrm{n}^{\mathrm{o}}$ & $\mathrm{n}^{\mathrm{o}}$ & $\mathrm{n}^{\mathrm{o}}$ & $\mathrm{n}^{\mathrm{o}}$ & $\mathrm{n}^{\mathrm{o}}$ & $\mathrm{n}^{\mathrm{o}}$ \\
\hline Bassethound & 5 & 4 & 1 & - & - & - & - & 3 & 2 \\
\hline Beagle & 6 & - & 4 & - & - & 2 & - & - & 6 \\
\hline Cocker Spaniel & 21 & 2 & 2 & 4 & 9 & 4 & - & 15 & 6 \\
\hline Collie & 3 & - & 3 & - & - & - & - & 1 & 2 \\
\hline Dachshund & 2 & - & 2 & - & - & - & - & - & 2 \\
\hline Brazilian Fila & $\mathrm{n}^{\mathrm{o}} 12$ & 3 & 2 & - & 5 & 2 & - & 8 & 4 \\
\hline Labrador & 1 & 1 & - & - & - & - & - & 1 & - \\
\hline Mastim Napolitanc & 2 & - & 2 & - & - & - & - & 2 & - \\
\hline Old English & 2 & - & 2 & - & - & - & - & - & 2 \\
\hline \multicolumn{10}{|l|}{ Sheepdog } \\
\hline German Shepherd & 13 & - & 4 & 3 & 2 & 2 & 2 & 9 & 4 \\
\hline Belgium Shepherd & 4 & - & - & 4 & - & - & - & 4 & - \\
\hline Poodle & 9 & 4 & - & 1 & - & 2 & 2 & 5 & 4 \\
\hline Rottweiler & 2 & - & 2 & - & - & - & - & 2 & - \\
\hline Saint Bernard & 1 & - & - & 1 & - & - & - & 1 & - \\
\hline Brazilian Terrier & 2 & - & - & - & - & 2 & - & - & 2 \\
\hline Yorkshire Terrier & 1 & - & 1 & - & - & - & - & 1 & - \\
\hline WDB & 14 & - & 6 & - & 3 & 5 & - & 7 & 5 \\
\hline no information & 02 & - & - & - & - & - & 2 & - & 2 \\
\hline Total & 102 & 14 & 31 & 13 & 19 & 19 & 6 & 61 & 41 \\
\hline
\end{tabular}

Group I = samples of healthy auditory tubes; Group II = samples of external otitis; $\mathrm{n}^{\mathrm{o}}=$ number of samples; $\mathrm{NI}=$ no information; $\mathrm{M}=$ male; $\mathrm{F}=$ female; $\mathrm{WDB}=$ Without defined breed.

In Group II (external otitis), more than 10 cells of $M$. pachydermatis per microscopic field was observed in 53 cases $(52.0 \%)$. The remaining samples presented the following results: $20(19.6 \%)$ between six and ten cells per field, 16 $(15.7 \%)$ from one to five cells and $13(12.7 \%)$ showed no cells 
Table 2. Results of direct exam and isolation of M. pachydermatis in healthy auditory tubes and external otitis from Southern and Midwest regions of Rio Grande do Sul, Brazil (1996 - 1997).

\begin{tabular}{ccccccc}
\hline DIRECT EXAM & \multicolumn{7}{c}{ ISOLATION M. PACHYDERMATIS } \\
\hline & GROUP I & & GROUP II & \\
\hline & Pos & Neg & Total & Pos & Neg & Total \\
& $\mathrm{n}^{\circ}(\%)$ & $\mathrm{n}^{\circ}(\%)$ & $\mathrm{n}^{\circ}(\%)$ & $\mathrm{n}^{\circ}(\%)$ & $\mathrm{n}^{\circ}(\%)$ & $\mathrm{n}^{\circ}(\%)$ \\
\hline$(+++)$ & - & - & - & $52(51.0)$ & $1(1.0)$ & $53(52.0)$ \\
$(++)$ & - & $1(3.1)$ & $1(3.1)$ & $17(16.7)$ & $3(2.9)$ & $20(19.6)$ \\
$(+)$ & $5(15.6)$ & $1(3.1)$ & $6(18.7)$ & $6(5.9)$ & $10(9.8)$ & $16(15.7)$ \\
$(-)$ & $7(21.9)$ & $18(56.3)$ & $25(78.2)$ & $3(2.9)$ & $10(9.8)$ & $13(12.7)$ \\
\hline TOTAL & $12(37.5)$ & $20(62.5)$ & $32(100)$ & $78(76.5)$ & $24(23.5)$ & $102(100)$ \\
\hline
\end{tabular}

Group I = samples of healthy auditory tubes; Group II = samples of external otitis; $n^{\circ}=$ number of samples; $\%=$ percent; Pos = positive; $\mathrm{Neg}=$ negative; $(+++)=$ more than 10 cells de M. pachydermatis; $(++)=$ from 6 to 10 cells de M. pachydermatis; $(+)=$ from 1 to 5 cells de $M$. pachydermatis; $(-)=$ negative.

(Table 2). Statistical significant difference was demonstrated $(\mathrm{p}<0.01)$, in relation to a greater number (more than ten) of cells of M. pachydermatis for Group II than the Group I. Our results were not in acordance with Ribeiro et al. (21), who found higher number of cells of M. pachydermatis in infected $(40.0 \%)$ and healthy $(37.5 \%)$ animals. However, our results were close to Kiss et al. (13), who analyzed dogs with external otitis by the fluorescent technique, and observed larger numbers of yeast cells, proposing that more than ten cells per microscopic field is indicative of pathogenicity (18).

\section{Isolation of M. pachydermatis}

The isolation of M. pachydermatis was larger $(\mathrm{p}<0.01)$ in dogs with external otitis (Group II) in relation to the healthy one (Group I). M. pachydermatis was isolated in $12(37.5 \%)$ out of 32 samples of Group I and in 78 (76.5\%) of the samples of Group II (Table 2). This difference was larger than that observed by Feigl et al. (4) in otitis (50.6\%) and healthy auditory tubes $(43.8 \%)$. The presence of yeast in healthy auditory tubes was also found by Fraser (7) and Langoni et al. (15) (36.0\% and $43.0 \%$ respectively). On the other hand, Nunes and Hamdan (20) reported the isolation of M. pachydermatis in $91 \%$ of samples from healthy dogs. However, these authors did not mention if the dogs were examined for subclinical otitis.

M. pachydermatis was the cause of otitis in $76.5 \%$ of the affected dogs. Similar results are reported by Kiss et al. (13) and Szynkiewicz et al. (24) who mentioned that the yeast was responsible for $76.3 \%$ and $71 \%$ of the cases of otitis, respectively. In other reports, the frequency of $M$. pachydermatis as the cause of otitis ranged from $8 \%$ to $44 \%(5,7,8,9)$. In $51.3 \%$ (40 samples) of the infections by $M$. pachydermatis, the otitis was waxy and erythematous as mentioned by other authors $(8,9,10,13,16)$. In $15.4 \%$ (12 samples) of the cases, the otitis was purulent. 3.8\% (three samples) of the dogs had ulcerations, and in $29.5 \%$ of them (23 samples) the otitis was a combination of clinical signs and lesions.
The number of samples isolated with more than ten cells per field was larger $(p<0.01)$ comparing to the other scores, what justifies the use of the direct examination with cell counting for the initial diagnosis of the malasseziosis. In the samples of Group II, which presented more than ten cells in the direct examination, the isolation occurred in $52(98.1 \%)$, while the 13 samples with negative result in the direct examination, $M$. pachydermatis was isolated in three (23\%). Of the samples of Group I, $M$. pachydermatis was isolated in five $(22.7 \%)$ that presented from one to five cells per field in the direct examination and in seven (18.4\%) of the 25 negative samples (Table 2).

There were no statistical differences for sex, breed, age and ear conformation in relation to the isolation of $M$. pachydermatis. The otitis externa was much more frequent in Cocker Spaniel (14 - 21.9\%), German Shepherd (13 - 20.3\%) and Brazilian Fila (8 - 12.5\%) (Table 3). The first two breeds were also mentioned by Kiss et al. (13) and Giorgi et al. (9).

M. pachydermatis was isolated in only $50.0 \%$ (six samples) of pendular ears and 33.3\% (four samples) of erect ones in Group I, but in the group II $71.6 \%$ (48 samples) of the pendular ears and $92.3 \%$ (24 samples) of the erect ones (Table 4). The results obtained were similar to Baxter (1), who obtained in healthy pendular ears $59.0 \%$ of $M$. pachydermatis and $23.0 \%$ in the erect ones. Our data from pendular ears of group II was also similar to Baxter (1) in $71.0 \%$ of samples. In spite of the great frequency of isolation in dogs with erect ears, the majority of the otitis samples (48 out 67) came from dogs with pendular ears, reinforcing the affirmative of Stewart (23) who indicated the pendular ears as a predisposing factor for the establishment of otitis. The results obtained also agree with Lobell et al. (17), who considered the pendular ears a predisposing condition for otitis, although dogs with erect ears, mainly the German Shepherd, are also susceptible.

Most of the samples coming from dogs with otitis were of chronic evolution (72 samples), in which M. pachydermatis was isolated in $61(84.7 \%)$, but was also cultured from $50 \%$ of six 
cases of acute evolution. The great majority of cases (93 samples) were bilateral otitis, and M. pachydermatis was isolated in $78.4 \%$ of the cases. Similar results were reported by Gentilini et al. (8) and Smith (22).

It is quite interesting to mention that during the same period of this study (96/97), Ferreiro et al. (6) notified an increased incidence (3.5\% of 1399 samples) of this yeast among other agents of dermatomycoses in a different region of the Rio Grande do Sul state, in comparison with previous data (79/83).

\section{Other etiological agents}

From 32 positive samples for M. pachydermatis (Group I), only two (6.3\%) presented Staphylococcus intermedius. In samples of group II, besides M. pachydermatis, it was also isolated the yeast Candida albicans (2.0\%), and the following bacteria: Staphylococcus intermedius (25.5\%), Staphylococcus aureus (17.6\%), Pseudomonas aeruginosa (15.7\%), Proteus sp (10.8\%), Streptococcus sp (6.9\%), Staphylococcus epidermidis (5.9\%), Actinomyces sp (5.9\%). There was no bacterial growth in $11.8 \%$ samples. The most frequent agents isolated in samples from Group II were M. pachydermatis and Staphylococcus sp, similar to the results found by other authors $(3,6,10,14,25)$. The

Table 3. Distribuition of breeds with isolation of $M$. pachydermatis from healthy (Group I) and with external otitis (Group II) from Southern and Midwest regions of Rio Grande do Sul, Brazil (1996 - 1997).

\begin{tabular}{|c|c|c|c|}
\hline \multirow[b]{2}{*}{ BREEDS } & \multicolumn{3}{|c|}{ ISOLATION $M . P A C H Y D E R M A T I S$} \\
\hline & $\begin{array}{c}\text { GROUP I } \\
\mathrm{n}^{\circ}(\%)\end{array}$ & $\begin{array}{c}\text { GROUP II } \\
n^{\circ}(\%)\end{array}$ & $\begin{array}{c}\text { TOTAL } \\
\mathrm{n}^{\circ}(\%)\end{array}$ \\
\hline Bassethound & $\ldots$ & $4(6.2)$ & $4(5.2)$ \\
\hline Beagle & $\cdots$ & $6(9.4)$ & $6(7.9)$ \\
\hline Cocker Spaniel & $2(16.7)$ & $14(21.9)$ & $16(21.0)$ \\
\hline Collie & - & $02(3.1)$ & $2(2.6)$ \\
\hline Dachshund & - & $02(3.1)$ & $2(2.6)$ \\
\hline Brazilian Fila & - & $08(12.5)$ & $8(10.5)$ \\
\hline Labrador & $02(16.7)$ & $01(1.7)$ & $3(3.9)$ \\
\hline Mastim Napolitano & - & $02(3.1)$ & $2(2.6)$ \\
\hline Old English Sheepdog & $\cdots$ & $02(3.1)$ & $2(2.6)$ \\
\hline German Shepherd & $02(16.7)$ & $13(20.3)$ & $15(19.7)$ \\
\hline Belgium Shepherd & $\cdots$ & $04(6.2)$ & $4(5.3)$ \\
\hline Miniature Pinscher & $02(16.7)$ & $\cdots$ & $2(2.6)$ \\
\hline Poodle & $02(16.7)$ & $02(3.1)$ & $4(5.3)$ \\
\hline Rottweiler & $\cdots$ & $02(3.1)$ & $2(2.6)$ \\
\hline Saint Bernard & - & $01(1.7)$ & $1(1.3)$ \\
\hline Schnauzer & $02(16.7)$ & $\cdots$ & $2(2.6)$ \\
\hline Brazilian Terrier & - & $01(1.7)$ & $1(1.3)$ \\
\hline Without defined breed & - & $14(17.9)$ & $14(15.6)$ \\
\hline Total & $12(100)$ & $78(100)$ & $90(100)$ \\
\hline
\end{tabular}

Group I = samples of healthy auditory tubes; Group II = samples of external otitis; $n^{\circ}=$ number of samples; $\%=$ percent. genera Streptococcus $(6.9 \%)$ and Proteus $(10.8 \%)$ presented a frequency not considered as high for these two agents of external otitis, in accordance with other authors $(3,5,13)$. Other secondary agents were also isolated apart form $M$. pachydermatis, as reported majority of authors $(3,5,8,9,10,13,24)$.

In samples from Group II the most frequent interaction was M. pachydermatis and Staphylococci (Table 5), which was also described by Fernandes and Gomes (5). The concomitant occurrence of Staphylococcus intermedius (27.0\%) and Staphylococcus aureus (23.1\%) with Malassezia pachydermatis, was very close, to that reported by these

Table 4. Results of isolation of M. pachydermatis from pendular, semipendular and erect ears, in healthy dogs (Group I) and with external otitis (Group II) from Southern and Midwest regions of Rio Grande do Sul state, Brazil (1996 - 1997).

\begin{tabular}{lrrr}
\hline \multicolumn{4}{c}{ ISOLATION OF $M$. PACHYDERMATIS } \\
\hline CONFORMAT & $\begin{array}{c}\text { POSITIVE } \\
\mathrm{n}^{\circ}(\%)\end{array}$ & $\begin{array}{c}\text { NEGATIVE } \\
\mathrm{n}^{\circ}(\%)\end{array}$ & \multicolumn{1}{c}{$\begin{array}{c}\text { TOTAL } \\
\mathrm{n}^{\circ}(\%)\end{array}$} \\
\hline GRO OF EARS & & & \\
\hline Pendular & $6(50.0)$ & $6(50.0)$ & $12(100)$ \\
Semi- pendular & $2(25.0)$ & $6(75.0)$ & $8(100)$ \\
Erect & $4(33.3)$ & $8(66.7)$ & $12(100)$ \\
\hline GROUP II & & & \\
\hline Pendular & $48(71.6)$ & $19(28.4)$ & $67(100)$ \\
Semi- pendular & $5(83.3)$ & $1(16.7)$ & $6(100)$ \\
Erect & $24(92.3)$ & $2(7.7)$ & $26(100)$ \\
No information & $1(33.3)$ & $2(66.7)$ & $3(100)$ \\
Total & $90(67.2)$ & $44(32.8)$ & $134(100)$ \\
\hline
\end{tabular}

Group I = samples of healthy auditory tubes; Group II = samples of external otitis; $\mathrm{n}^{\mathrm{o}}=$ number of samples; $\%=$ percent.

Table 5. Malassezia pachydermatis in monoculture and in interaction with bacteria in the 78 otitis samples (Brazil, RS, 1996 - 1997).

\begin{tabular}{lr}
\hline \multicolumn{1}{c}{ ISOLATIONS } & $\begin{array}{r}\text { GROUP II } \\
\mathrm{n}^{\circ}(\%)\end{array}$ \\
\hline Monoculture & $25(32.1)$ \\
Mixed infection & $53(67.9)$ \\
M. pachydermatis + Staphylococcus aureus & $16(20.5)$ \\
M. pachydermatis + Staphylococcus intermedius & $15(19.2)$ \\
M. pachydermatis + Proteus sp & $9(11.5)$ \\
M. pachydermatis + Actinomyces $\mathrm{sp}$ & $3(3.8)$ \\
M. pachydermatis + S. aureus + S.intermedius & $2(2.6)$ \\
M. pachydermatis + Pseudomonas aeruginosa & $2(2.6)$ \\
M. pachydermatis + S. intermedius + P. aeruginosa & $2(2.6)$ \\
M. pachydermatis + S. intermedius + Actinomyces & $2(2.6)$ \\
M. pachydermatis + Streptococcus sp & $2(2.6)$ \\
\hline Total & $78(100)$ \\
\hline
\end{tabular}


authors. The interaction between $M$. pachydermatis and Staphylococcus aureus, was significantly bigger, since $M$. pachydermatis was found together with the yeast in all the 18 isolations $(\mathrm{p}<0.01)$, while the association with $S$. intermedius was found in 21 out of 26 cultures. Other authors described association with $S$. intermedius or $S$. aureus as being more frequent $(3,4,13)$. The concomitant culture of Malassezia pachydermatis and Pseudomonas aeruginosa occurred in only four $(5.0 \%)$ cases of otitis, demonstrating no interaction ( $\mathrm{p}>0.05)$, which was already observed previously $(9,16,23)$.

\section{RESUMO}

\section{Ocorrência de Malassezia pachydermatis e de outros agentes etiológicos de otite externa em cães no estado do Rio Grande do Sul, BR (1996-1997)}

Este trabalho teve como objetivos estudar a ocorrência da Malassezia pachydermatis e de outros agentes etiológicos em cães com otite externa e com conduto auditivo externo hígido; caracterizar a otomicose por $M$. pachydermatis. Foram analisadas 32 amostras de cães com o conduto auditivo hígido e 102 de otite externa. Todas as amostras foram submetidas ao exame direto, cultivo em ágar sangue e em ágar Sabouraud dextrose acrescido de cloranfenicol e cicloheximida. Ao exame direto $52.0 \%$ das amostras de otite apresentaram mais de dez células de $M$. pachydermatis. Somente $21.8 \%$ das amostras de orelhas hígidas apresentaram no exame direto células com esta morfologia (uma a dez células). M. pachydermatis foi isolada em $37.5 \%$ das amostras do conduto auditivo hígido e em $76.5 \%$ das amostras de otite $(\mathrm{p}<0.01)$. Foi freqüente a associação entre Malassezia pachydermatis e Staphylococcus aureus $(\mathrm{p}<0.01)$ enquanto a associação da levedura com Pseudomonas aeruginosa não foi comum ( $\mathrm{p}>0.05$ ). A infecção por $M$. pachydermatis foi prevalente em cães da raça Cocker Spainel, Pastor Alemão e Fila Brasileiro, não tendo sido demonstradas diferenças para idade, sexo e conformação do pavilhão auricular. A otomicose foi predominantemente ceruminosa e eritematosa. M. pachydermatis foi o agente com maior prevalência nas otites externas.

Palavras-chave: Malassezia pachydermatis, Staphylococcus aureus, otites, cães

\section{REFERENCES}

1 - Baxter, M. Pityrosporum pachydermatis and erect ears in pendulous of dogs. New Zeland Vet. J., 24:69-70, 1976.

2 - Bond, R.; Anthony R.M. Characterization of markedly lipiddependent Malassezia pachydermatis isolates from healthy dog. $J$. Appl. Bact., 78:537-542, 1995.
3 - Bornand, V. Bactériologie et mycologie de lótite esterne du chien. Schweiz. Arch. Tierheilk, 134:1-8, 1992.

4- Feigl, M.H.; Mós, E.N.; Larsson, C.E.; Santos, M.A.A. Estudo microbiológico das otitis externas em cães. Rev. Microbiol., São Paulo, 12:89-91, 1981

5 - Fernandes, J.C.T.; Gomes, M. Flora bacteriana e fúngica de cães com otitis atendidos pelo Hospital de Clínicas Veterinárias da UFRGS. Arq. Fac. Vet. UFRGS, Porto Alegre, 7:97-103, 1979.

6 - Ferreiro, C.L.R.; Berg, V.; Quadrado, S.S.; Ferreiro, L. Comparação da incidencia dos agentes etiológicos das dermatomicoses dos carnívoros domésticos na região da grande Porto Alegre - RS Brasil. XXV Congresso Brasileiro de Medicina Veterinária, Gramado, 1997, p.152.

7- Fraser, G. The fungal flora of the canice ear. J. Comp. Pathol., 71:1$5,1961$.

8 - Gentilini, E.; Denamiel, G.A.A; Escalada, J.; Neyra, J. Otitis canina cronica hallazgos microbiologicos y sensibilidad a los antibioticos. Vet. Arg.,. 8:113-117, 1991.

9- Giorgi, W.; Martin, C.M.; Schmidt, E.F. Principais agentes etiológicos da otitis externa em cães. Pet Vet., 2:15-17, 1996.

10 - Griffin, C. Limpeza e terapia tópica das otitis. A Hora Vet., 94:1725, 1996.

11 - Guillot J. Taxonomie et phylogénie des levures du genre Malassezia. Paris, 1995, 225p (Ph.D. Thesis. Faculté de Medicine de Créter, Université Paris XII Val de Marne).

12- Guého, E.; Midgley, G.; Guillot, J. The genus Malassezia with description of four new species. Antonie van Leeuwenhock, 69:337$355,1996$.

13- Kiss, G.; Radványi, Sz.; Szigeti, G. New combination for the therapy of canine otitis externa. I microbiology of otitis externa. J. Small Anim. Pract., 38:51-56, 1997.

14- Lacaz, C.S.; Porto, E.; Heins-Vaccari, E.M.; Melo, N.T. Identificação dos fungos. In: Fungos Actinomicetos Algas de interesse médico, Sarvier, São Paulo (Brasil), 1998, p.130.

15- Langoni, H.; Fessel, Y.M.N.; Listoni, F.J.P.; Fava, N. Microflora aeróbica de ouvido de cães sem otitis. Arq. Bras. Med. Vet.Zotec., 43:255-260, 1991.

16- Larsson, C.E.; Larsson, M.H.M.A.; Amaral, R.C.; Gandra, C.R.P.; Hagiwara, M.K.; Fernandes, W.R. Dermatitis in dogs caused by Malassezia (Pityrosporum) pachydermatis. Ars Vet., 4:63-68, 1988.

17 - Lobell, R.; Weingarten, A.; Simmons, R. Um novo agente para o tratamento da otitis externa canina. A Hora Vet., 88:29-33, 1995.

18- Macy, D.W. Moléstias do aparelho auditivo. In: Ettinger, S.J. (ed) Tratado de medicina interna veterinária, Manole Ltda, São Paulo, 1992, p.256-276.

19- Mansfield, P.D.; Boosinger, T.R.; Attleberger, M.H. Infectivity of Malassezia pachydermatis in the external ear canal of dogs. J.A.A.H.A., 26:97-100, 1990.

20- 20-Nunes, B.M.; Hamdan, J.S. Prevalência de Malassezia pachydermatis no conduto auditivo externo de cães sadios. XXIII Congresso de Microbiologia, Santos, 1995, p.132.

21 - Ribeiro, V.L.S.; Pereira, S.A.; Dieckmann, A.M. Ocorrência de Malassezia pachydermatis em número elevado nos condutos auditivos externos sãos e com otite externa de cães. XXV Congresso Brasileiro de Medicina Veterinária, Gramado, 1997, p.149.

22- Smith, J.M. The association of yeast with chronic otitis externa in the dog. Aust. Vet. J., 44:413-415, 1968.

23 - Stewart, L.J. Newly reported skin disease syndromes in the dog. Vet. Clin. North Am. (Small Anim. Pract.), 20:1603-1613, 1990.

24- Szynkiewicz, Z.; Binek, M.; Kozanecki, C.; Dworecka, B.; Paralinska, M. Bacteriological and mycological skin and ear infections in dogs. In: Jeljaszewicz/Ciborowski (eds). The Staphylococci. GustavFischer Verlag, New York, 1991, p.471-472. 